\title{
Histo-morphologic Spectrum of Non-Hodgkin Lymphoma According to WHO Classification 2016: A Cross-Sectional Study
}

\author{
Yasmin $\mathrm{S}^{\mathrm{a}}$, Haque WS ${ }^{\mathrm{b}}$, Islam SMJ ${ }^{\mathrm{c}}$, Ahmed I ${ }^{\mathrm{d}}$, Hossain S $\mathrm{S}^{\mathrm{e}}$, Saha $\mathrm{D}^{\mathrm{f}}$
}

\begin{abstract}
Background: Geographic variations with regard to incidence and histological subtypes are known to occur in Non-Hodgkin lymphoma (NHL). This study was aimed to see the incidence and subtypes of NHL in a group of Bangladeshi population.

Methods: This cross sectional study was carried out in Armed Forces Institute of Pathology (AFIP) Bangladesh, from 1st April 2017 to 31st March 2018. All nodal and extranodal tissues which were morphologically diagnosed as NHL were included in the study and immunohistochemistry was done for sub-classification according to WHO classification 2016. Bone marrow trephine biopsy samples were excluded.

Results: Total cases: 106, mean age: 48.5 years \pm 18.5 (range $2 Y 9 M-82$ years), male-female ratio: 2.2:1. Total subject of B cell Lymphoma (BNHL): 83 (78.3\%) and T cell lymphoma (TNHL): 23 (21.7\%). Among BNHL, total subjects of diffuse large B cell lymphoma (DLBCL) 50 (60\%), follicular lymphoma 9 (11\%), marginal zone lymphoma 8 (10\%), small cell lymphoma and mantle cell lymphoma 5 (6\%) each, Burkitt lymphoma 4 (5\%) and B cell lymphoblastic lymphoma 2 (1.89\%) in number. Among TNHL peripheral T-cell lymphoma NOS 11 (48\%), anaplastic large cell lymphoma (ALCL) 5 (22\%), T cell lymphoblastic lymphoma 4 (17\%), and angio-immunoblastic T cell lymphoma 3 (13\%) in number. Among 5 ALCL, 4 ALK positive and 1 ALK negative. Number of primary extra-nodal NHL were 29 (27\%) with most common involved organ system being GIT and most common histological subtype being DLBCL.

Conclusion: Quite similar pattern of age range with mean age, male to female ratio, subtypes and extra nodal NHL distribution prevailing in our subcontinent is found in our population with subtle increased incidence of TNHL indicating the necessity of further large epidemiological study.
\end{abstract}

Keywords: Non Hodgkin lymphoma (NHL), Immuno-histochemistry (IHC).

Author Information

a. Dr. Shamoli Yasmin MBBS, MCPS, DCP, FCPS (Histopatology). Classified Specialist in Pathology, AFIP, Dhaka

b. Dr. Wasim Selimul Haque MBBS, MCPS, DCP, FCPS (Histopatology). Classified Specialist in Pathology, AFIP, Dhaka

c. Dr. SK Md. Jaynul Islam MBBS, MCPS, DCP, FCPS (Histopatology). Classified specialist and HOD, Histopathology, AFIP, Dhaka

d. Dr. Ishtyaq Ahmed MBBS, MCPS, DCP, FCPS (Histopatology). Asstt. Prof, pathology, Armed Forces Medical College, Dhaka

e. Dr. Sowkat Hossain MBBS, MCPS, DCP, FCPS (Histopatology). Classified Specialist in Pathology, AFIP, Dhaka

f. Dr. Debashish Saha MBBS, FCPS (Chem Path), MMEd. Commandant AFIP, Dhaka

Address of Correspondence: Dr. Shamoli Yasmin MBBS, MCPS, DCP, FCPS (Histopatology). Classified Specialist in Pathology, AFIP, Dhaka

Received: May 19, 2018

Accepted: July 31, 2018

\section{Introduction}

Lymphoma is a generic term given to tumours of lymphoid system, specifically of lymphocytes and their precursor cells. Two major categories of lymphomas are Hodgkin lymphoma (HL) and non-Hodgkin lymphoma (NHL). ${ }^{1}$ The classification of NHL that was most widely used until early 1980s in US and many other countries was the Rappaport classification. ${ }^{1,2}$ There after Working classification proposed in 1982 and REAL classification introduced in 1994 were being used. ${ }^{3}$ With advance in the field of immunohistochemistry (IHC) and genetics, WHO classification was proposed in 2001 and has been recently revised in 2016 where both the HL and NHL have been subclassified basing on morphology, IHC, genetic 
abnormality, genomics and proteomics. ${ }^{4}$ WHO classification has been adopted in many countries which helps in prognostication of NHL and selection of appropriate therapy including targeted therapy. ${ }^{5}$

NHL is the $8^{\text {th }}$ most commonly diagnosed malignancy in male, and the $11^{\text {th }}$ in female. The disease account for $5.1 \%$ of all cancer cases and $2.7 \%$ of all cancer deaths. ${ }^{6}$ World-wide incidence of NHL is increasing faster. The reason for this pattern of increased rate is largely unknown but at least partly attributable to diagnostic improvements. Various genetic, environmental and occupational factors are also associated with increased risk of NHL. ${ }^{7}$ Moreover there is variation in pattern and distribution of different subgroups of NHL in different areas of the world. B-cell NHL (BNHL) is more prevalent in all over the world accounting for about $80 \%$ of all NHL. Incidence of T-cell NHL (TNHL) is more in Asian countries than in the western countries. ${ }^{9}$

In our country IHC is being conducted in some tertiary laboratories only. After thorough search in pubmed citations, it is assumed that only one study is reported on NHL in our country after adoption of WHO classification..$^{10}$ Therefore, we conducted this study to observe the pattern of different subtypes of NHL as well as its distribution among different age and sex group in a small portion of Bangladeshi population.

\section{Methods}

A cross sectional study on 106 morphologically diagnosed NHL cases reported in Department of Histopathology of Armed Forces Institute of Pathology (AFIP) Dhaka was carried out from 01 April 2017 to 31 March 2018. AFIP is a tertiary care laboratory which receives specimens not only from all the military hospitals of Bangladesh but also from many civil hospitals all over the country. All the specimens were received in $10 \%$ formalin, embedded in paraffin, sectioned and stained with hematoxyllin and eosin $(\mathrm{H}$ \& E) stain. The biopsy specimens in which the provisional diagnosis of NHL was done by careful morphological assessment were included in the study. The bone marrow trephine biopsy specimens with diagnosis of lymphomatous infiltration were excluded from the study.

All the morphologically diagnosed NHL cases were treated with IHC panel for classification according to WHO 2016.
Before immunostaining three to four micrometer sections were taken on sialinized slides (DAKOS300330) then these were de-waxed in xylene and rehydrated in graded ethanol. Antigen retrieval was performed in PT module. As per instruction manual of manufacturer, immunostaining was done. Antibody detection was done by DAKO Envision detection system. All the slides were evaluated. Pattern of positivity with awareness of associated caveats were taken into account for the accurate sub-typing and distinguishing from reactive process.

The initial panel of IHC antibodies included CD20 as B cell marker, CD3 as T-cell markers and ki67 as proliferative marker. During morphological assessment certain specific anatomic architectural characteristics were taken into account. Panel of antibodies was decided based on morphological pattern. Morphologic features evaluated were effacement of lymph nodal architecture (diffuse or nodular), size of cells (small/ medium to large size), size and shape of nucleus, nature of chromatin (fine/course/vesicular), presence of nucleoli (single/multiple) and amount of cytoplasm (scant/moderate/abundant).

CD20 positive BNHLs having large cells were categorized as diffuse large B cell lymphoma (DLBCL). BNHL having small cells showing diffuse growth pattern were treated with CD23 and cyclinD1. Cyclin D1 positivity indicated mantle cell lymphoma (MCL) and CD23 positivity indicated small cell lymphoma (SLL). If both the markers were negative CD5, CD43 and CD10 were used for categorization of marginal zone lymphoma (MZL) where all the markers are negative.

BNHL with nodular or follicular pattern of proliferation, IHC panel of CD10, BCL6 and BCL2 were used as for diagnosis of Follicular lymphoma (FL) and differentiation from reactive lymphadenitis. FL was suggested if BCL2 was negative and BCL6 or CD10 was found positive. If all 3 were found negative then CD23, cyclinD1, CD43 and CD5 were used to categorize the lesion as SLL, MCL or MZL. MCL was diagnosed with positive cyclin D1, SLL diagnosis was done on basis of CD23 positivity, MZL was diagnosed when all the markers were found negative. BNHL with very high Ki67 having medium sized cells arranged in starry sky pattern with numerous tingible body macrophages were treated with CD10, c-MYC antibody for categorization of Burkitt lymphoma (BL).

CD3 positive T cell NHL (TNHL) tissue sections were treated with $\mathrm{CD} 5, \mathrm{CD} 7$ and $\mathrm{CD} 2$ for diagnosis of peripheral T-cell lymphoma (PTCL, NOS). If 
morphology suggested angio-immunoblastic $\mathrm{T}$ cell lymphoma (AITCL), CD21 or CD23 was added in the panel of IHC antibody for confirmation of presence of abnormal meshwork composed of follicular dendritic cells in the perivascular zone. CD10 or PD1 antibody was used to detect the proliferative follicular centre $\mathrm{T}$ lymphocytes. Cases morphologically resembled Anaplastic large cell lymphoma (ALCL) which were both negative for $\mathrm{CD} 3$ and $\mathrm{CD} 20$ were treated with CD30, ALK1, CD43, pancytokeratin and Pax5.

Tdt was added where the morphology was suggestive of blastic variant.

The results were studied and analyzed by Microsoft office excess version 10 .

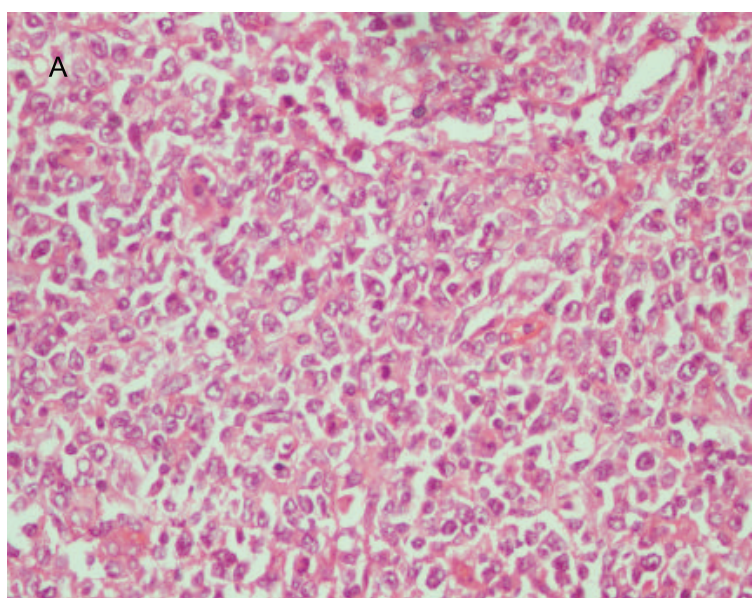

\section{Results}

A total number of 106 morphologically and immunohistochemically diagnosed NHL cases were included in the study. Among them 73 were male and 33 were female. Male female ratio was 2.2:1. Age range was from 2 year 9 month to 82 years, with mean age $48.5 \pm 18.5$ years.

Out of 106, BNHL was found in $83(78.3 \%)$ and TNHL was found in $23(21.7 \%)$ subjects. DLBCLwas the most frequent (50/83) subtype accounting $60 \%$ of B NHL (Fig-1). One DLBCL subject of 63 year old male was found having coexistent tuberculosis in the same lymph node. The $2^{\text {nd }}$ most frequent group was FL $(9 / 83)$ accounting $10.8 \%$ of BNHL (Fig-2). Four subjects of FL were categorized as grade 2 and the other 5 were
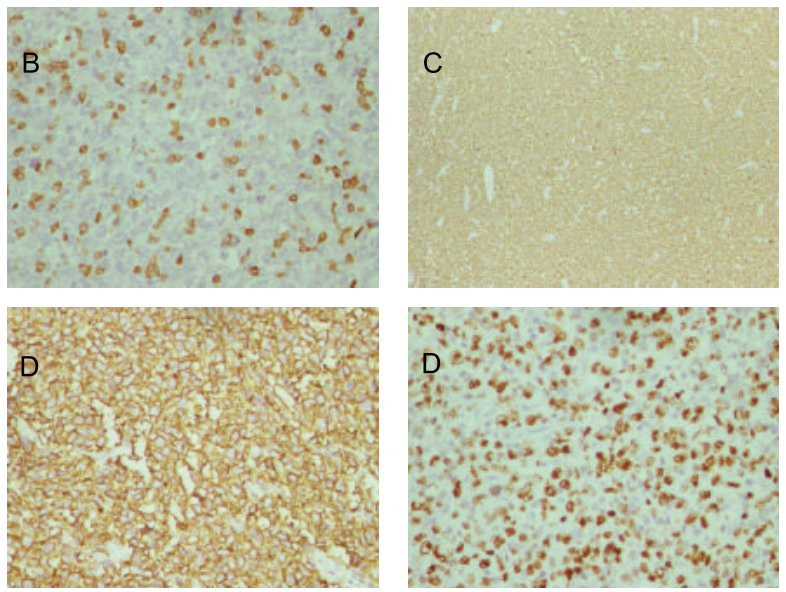

Figure 1 DLBCL. A: Diffuse proliferation of large lymphoid cells with few having prominent nucleoli (H\&E x 400), B: Neoplastic cells are CD3 negative (Immunostaining x40), C. CD20 positive (Immunostaining x40), D. CD20 in higher magnification (Immunostaining x100), E). Ki 67 showing high proliferation index (Immunostaining x100).
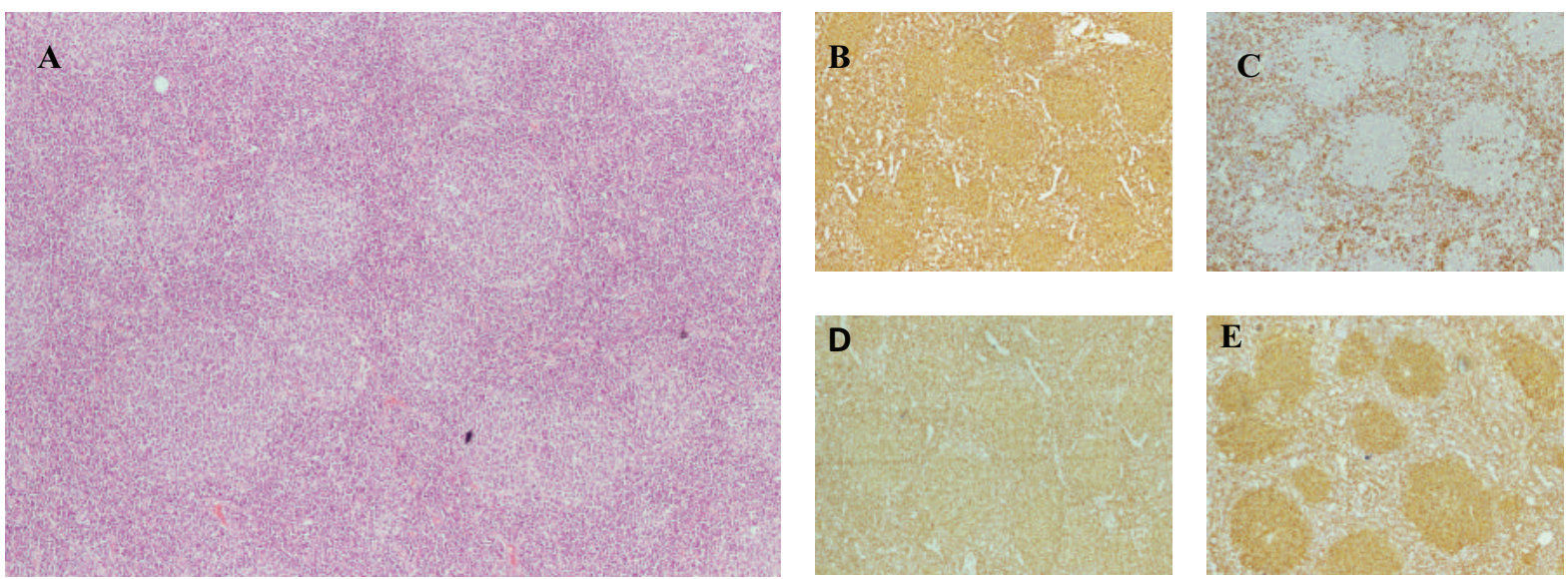

Figure 1 FL. A: Follicular pattern of growth (H\&E x 100). B. Neoplastic cells are CD10 positive (Immunostaining x 100), C. CD3 negative (Immunostaining x100), D. BCL2 positive (Immunostaining x100), E). CD10 positive (Immunostaining x100) 
categorized as grade1. Next frequent group was MZL with $8(9.64 \%)$ subjects. MCL (Fig-3) and SLL each constituted $6 \%$ of BNHL, each affecting 5 subjects. One MCL was categorized as blastoid variant. BL (Fig-4) occurred in 4 subjects forming $4.82 \%$ of BNHL. B ALL affected 2 subjects accounting $1.88 \%$ of BNHL.

PTCL, NOS was the most common subtype with 11 (47.83\%) subjects among 23 subjects of all TNHL. In one of the PTCL, NOS subject of 7 year old male, molecular study was advised as IHC could not give a conclusive diagnosis. Next frequent group was ALCL involving 5 (21.74\%) subjects, 4 of them were ALK 1 positive and 1 was ALK 1 negative (Fig-5). Four (17.39\%) subjects of T ALL and 3 (13\%) subjects of AITCL (Fig-6) were present in our study.
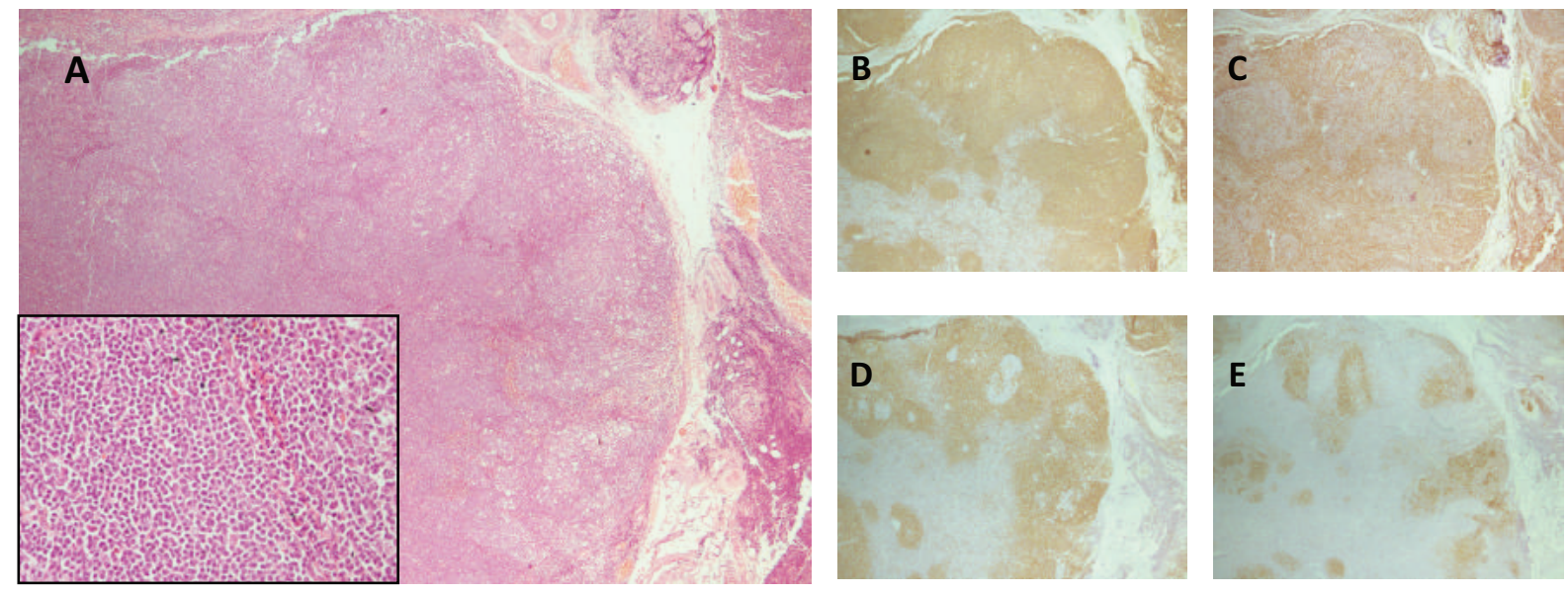

Figure 3 MCL. A: Vaguely nodular pattern of growth of neoplastic cells (H\&E x 40), inset showing small to medium sized neoplastic cells having slightly irregular nuclei (H\&E x 400), B: Neoplastic cells are CD 20 positive (Immunostaining x40), C. Tumor cells are CD3 Negative, CD3 positive reactive T cells are surrounding neoplastic nodules (Immunostaining x40), D. Tumor cells are positive for Cyclin D1 and involving marginal zone predominantly (Immunostaining x40), E). CD 23 showing presence of abnormal meshwork of follicular dendritic cells (Immunostaining $\mathrm{x} 40$ ).
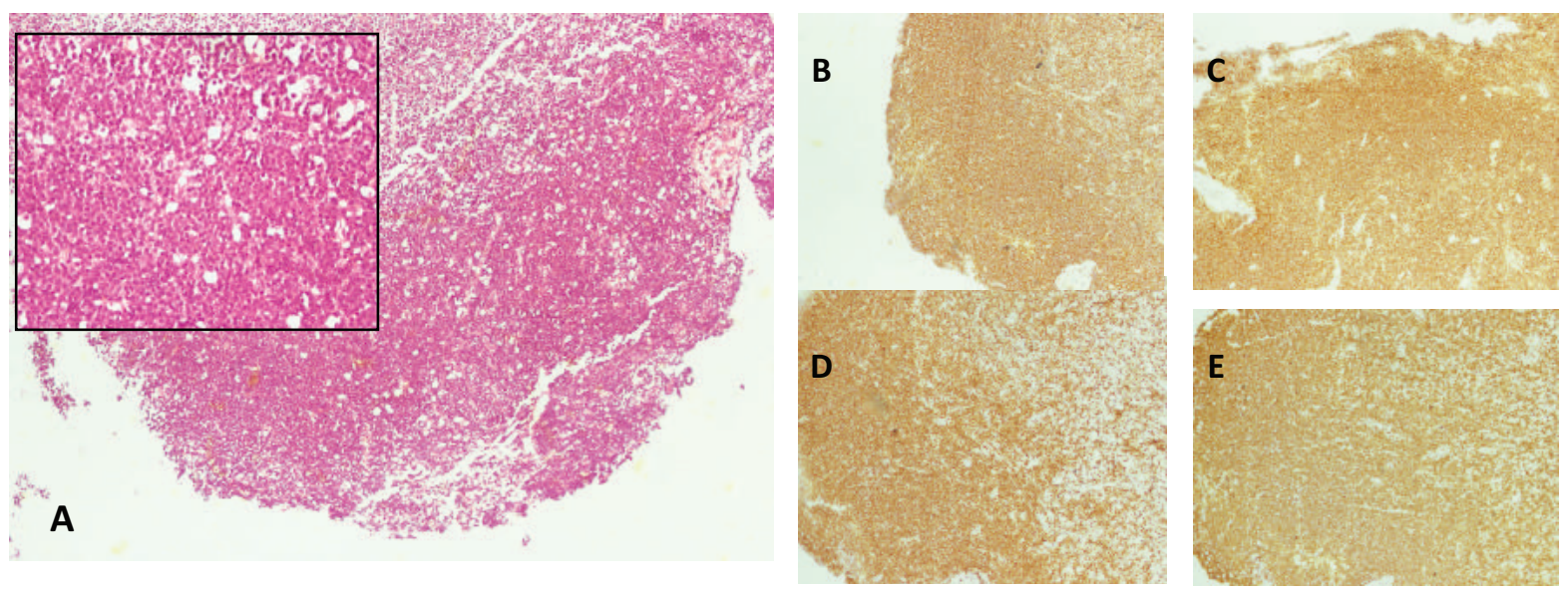

Figure 4 BL. A: Diffuse proliferation of tumor cells with characteristic 'starry sky' pattern (H\&E x 40), inset showing medium sized neoplastic cells having round nuclei with finely clumped chromatin (H\&E x 400), B: Neoplastic cells are CD 20 positive (Immunostaining x40), C. Tumor cells are CD10 positive (Immunostaining $\mathrm{x} 40$ ), D. Tumor cells are positive for C-MYC (Immunostaining x40), E). Ki67 shows very high proliferative index approaching 100\% (Immunostaining x40). 

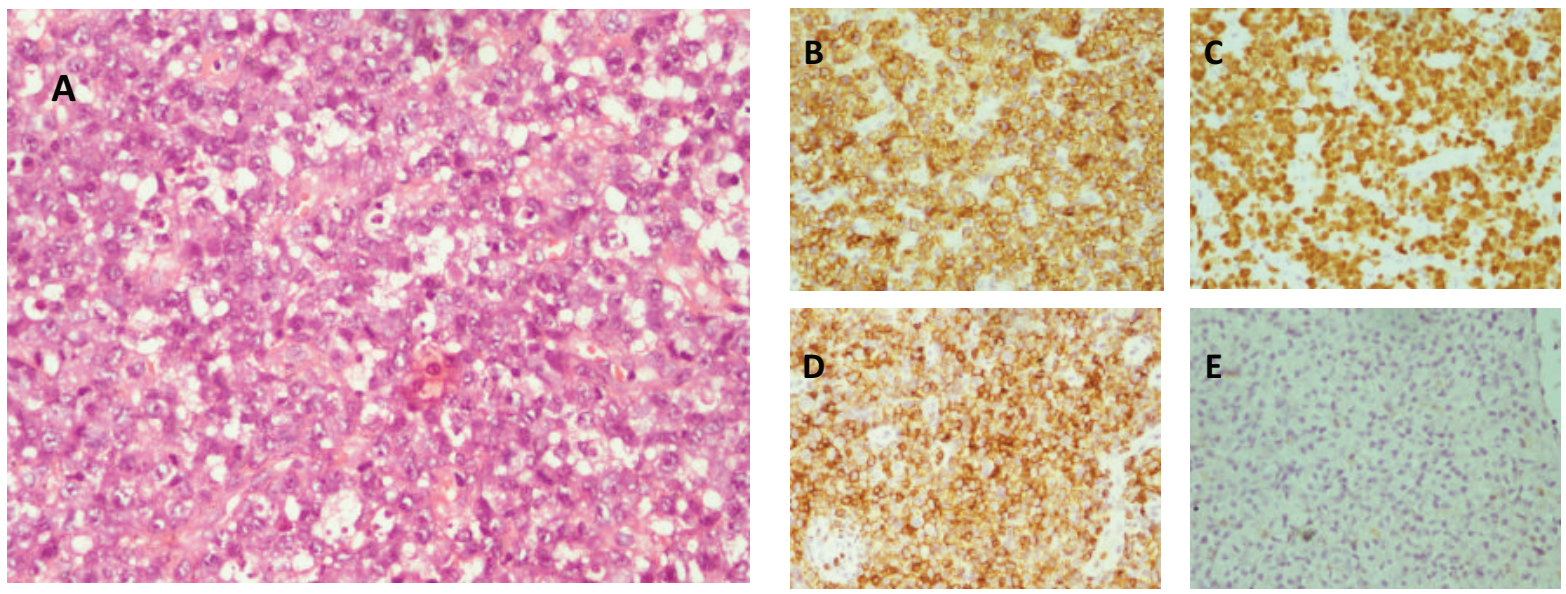

Figure 5 ALCL. A: Diffuse proliferation of predominant population of large cells with irregular nuclei (H\&E x 400), B: Neoplastic cells are CD 30 positive (Immunostaining x100), C. Tumor cells are ALK-1 positive (Immunostaining x100), D. Tumor cells are positive for CD 43 (Immunostaining x100), E). Tumor cells are negative for CD 79a (Immunostaining x100).
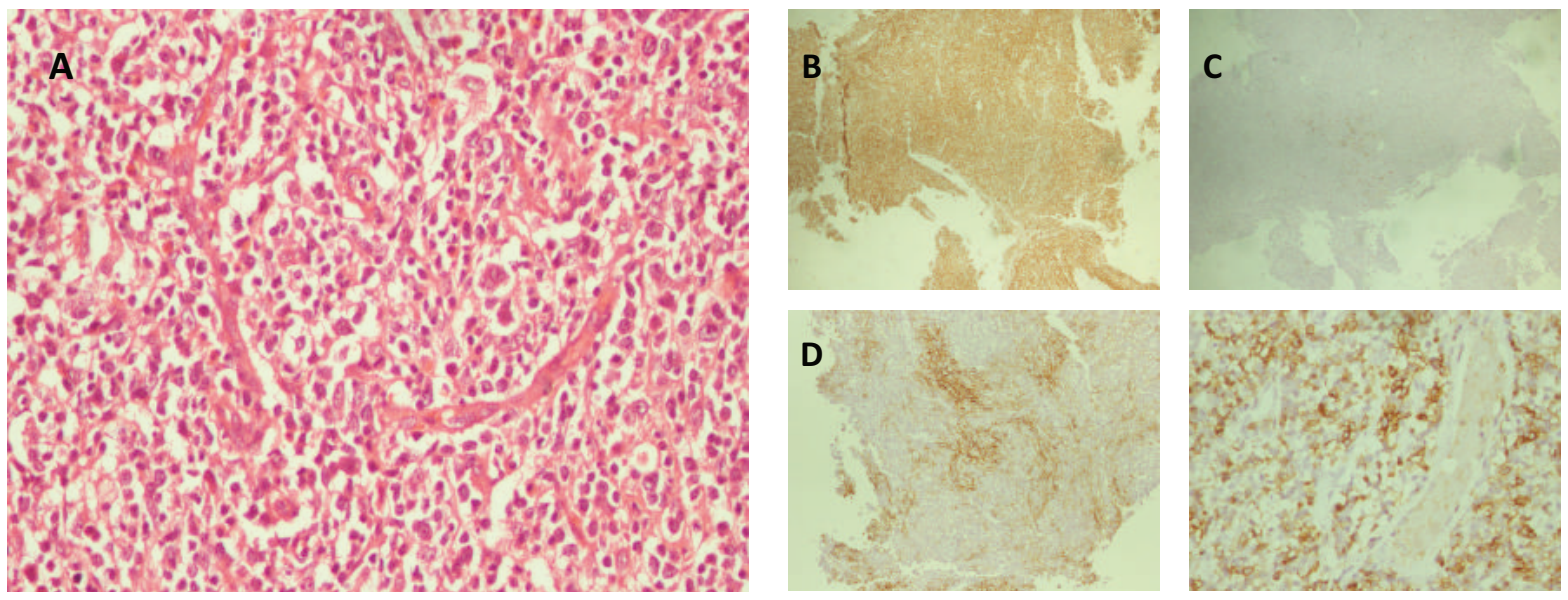

Figure 6 AITL. A: Small to medium sized neoplastic lymphocytes, with clear cytoplasm in a polymorphous inflammatory background and conspicuous arborizing blood vessels (H\&E x 100), B. Neoplastic cells are CD3 positive (Immunostaining x40), C. Virtually no CD20 positive B lymphocytes are present (Immunostaining x40), D. Characteristic disorganised follicular dendritic cell meshworks evidenced by CD23 immunostaining encircling blood vessels (Immunostaining x40), E). Numerous PD-1 positive T cells surrounding blood vessels (Immunostaining $\mathrm{x} 100)$.

NHL histological subtypes of the study subjects according to age groups is shown in Table I.

Out of 106 NHL, 77 (72.64\%) were primary nodal and $29(27.36 \%)$ were primary extra-nodal in origin. Among the primary extra-nodal group 21 (72\%) were DLBCL, 3 MZL, 2 BL, 1 T ALL, 1 ALCL and 1 was PTCL,
NOS. Major organ system involved was GIT (6/29). The next most frequently involved organ was tonsil (5/ 29). Three subjects each of NHL originated from pharynx, testis and brain. Two extra-nodal origin of NHL was found to arise from thyroid and bone. One each extra-nodal NHL originated from thymus, tongue, pleura, eyelid and kidney. 
Table I Age group distribution of different subtype of NHL $(n=106)$

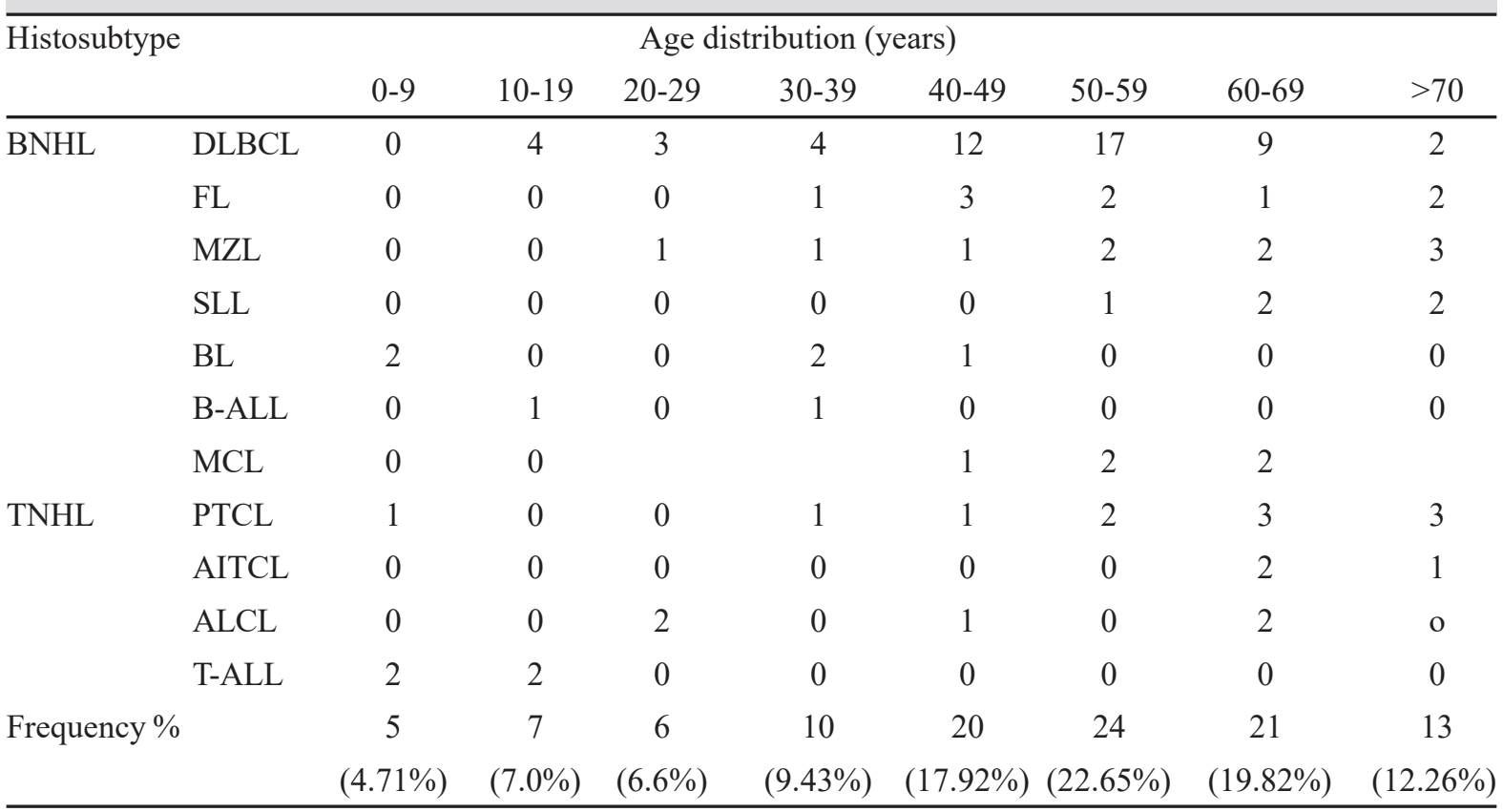

\section{Discussion}

NHLs are a heterogeneous group of malignancies of the immune system, encompassing more than 40 entities with specific clinical, morphologic, immunophenotypic, and molecular characteristics. ${ }^{8}$ The relative frequencies of various subtypes of non-Hodgkin lymphoma (NHL) vary significantly in different geographic regions of the world ${ }^{10-13}$ Environmental and lifestyle factors, as well as host genetic makeup appear to play an important role in the development of NHL ${ }^{14}$. Only one study was conducted in our country after adoption of WHO classification. ${ }^{9}$ Therefore we conducted this study by adopting WHO classification scheme 2016 with morphologically diagnosed different subtypes of NHL by applying IHC.

Out of 106 studied subjects 73 were male and 33 were female with male female ratio 2.2:1. In our study males were affected more than females. Similar male predominance is reported in various other studies conducted in different parts of the world. ${ }^{10-16}$ The less incidence of NHL among females may be explained by direct effects of estrogens on lymphoma cell proliferation or by its effect on anti-tumor immune response. ${ }^{17}$ Moreover, it is assumed that lack of access to health care facilities for women in our country may have contributed to significantly greater number of male subjects in our study.

Age range of the study was from 2 Y 9 month to 82 years. The mean age was $48.5 \pm 18.5$ years for all the subtypes of NHL. The present study demonstrated that NHL was most prevalent in the 6th decade. A Akhter et al also reported almost same mean age and most prevalent decade. ${ }^{9}$.Perry AM et al reported significantly lower mean age in the developing regions compared to developed nations. ${ }^{16}$ It is assumed that socioeconomic factors and certain infections may play a role in lymphomagenesis. ${ }^{16}$

Age group distribution of different subtypes was studied. Only 12 (11.3\%) subjects of different subtypes of NHL were found in first 2 decades with majority of subjects being lymphoblastic lymphoma. Study conducted by MT Marie et all in south India found similar finding. ${ }^{17}$ Pedrosal et al found disimillar finding in western countries and other eastern countries, where $>50 \%$ are Burkitt lymphoma ${ }^{19}$. Genetic predisposition appears to play a role in variation of pattern in childhood NHL. 19

Our study also showed that most of the elderly subjects of sixth and seventh decade have the highest incidence with major subtype of NHL being DLBCL. This finding is similar to various other studies. ${ }^{20,21}$ 
In our study $21.7 \%$ (23 cases) subjects were categorized as TNHL and $78.3 \%$ (83 cases) were as BNHL. Nair R, Arora N, Mallath M.K showed 10-15\% of NHL as TNHL in India. ${ }^{22}$ Krivolapov IuA reported $20 \%$ of all NHL as TNHL in a study conducted in Russia. ${ }^{23}$ Higher incidence of TNHL in our study indicates the necessity of large epidemiological study.

In our study DLBCL was the most frequent (50/83) subtype accounting $60 \%$ of BNHL. One DLBCL subject of 63 year old male was found to have coexistent tuberculosis in the same lymph node, which is a very rare finding with a very few case reports. ${ }^{24}$ The next most frequent group was FL (9/83) accounting $11 \%$ of BNHL. Four subjects of FL were categorized as grade 2 and the other 5 were categorized as grade 1 . Next frequent group was MZL with $8(10 \%)$ subjects. In MZL, 3 were extra-nodal in origin affecting ileum, testis and eyelid. Mantle cell lymphoma and SLL each constituted $6 \%(5 / 83)$, one of the MCL was of blastoid variety, which is a rare sub-variety. BL occurred in 4 subjects forming $5 \%$ of B NHL. In BL 2 were extranodal in origin affecting pharynx. B ALL affected 2 subjects, constituted $1.88 \%$ of BNHL.

In TNHL, the most frequent subtype was PTCL, NOS constituting 48\% (11/23), followed by ALCL 22\% (5/ 23), T ALL 17\% (4/23) and AITCL 13\% (3/23) of all TNHL. Almost similar distribution pattern was reported in a study conducted by Naresh KN, Srinivas V, Soman $\mathrm{CS}$ in India 25 Perry AM et al. found significance difference in distribution pattern of NHL between developed and developing world. ${ }^{16}$ These findings suggest that differences in etiologic and host risk factors are likely responsible, and more detailed epidemiological studies are needed to better understand these differences.

In our study out of the 106 cases of NHL, $77(73.58 \%)$ were primary nodal and $29(27 \%)$ were primary extra nodal in origin. Vannata B. in her study in China found $30 \%$ NHL were extra-nodal in origin, which is quite similar to our study. ${ }^{26}$ Gastro-intestinal tract (GIT) constituted the most common organ system in our study covering $21 \%$ of extra-nodal origin and DLBCL was the most common histological subtype. Similar finding was found in the study conducted by Pai A, Kannan T, Balambika RG in South India. ${ }^{27}$

\section{Conclusion}

Histomorphologic spectrum of NHL in our study shows almost similar pattern of distribution that has been prevailing in the subcontinent. A bit higher incidence of TNHL found in the study highlights the necessity of large epidemiological study in our country.

Conflict of interest: Nothing to declare.

\section{References}

1. Rosai J. Rosai and Ackerman's surgical pathology. Mosby an imprint of Elsevier. 2012 p 1807.

2. Nathwani BN. A critical analysis of the classifications of nonHodgkin's lymphomas. Cancer. 1979; 44: 347-84.

3. Aggarwal D, Gupta R, Singh S, Kudesia M. Comparison of working formulation and REAL classification of nonHodgkin's lymphoma: an analysis of 52 cases. Haematology. 2011;16: 195-99.

4. Swerdlow SH, Campo E, Harris NL, Jaffe ES, Pileri SA, Stein $\mathrm{H}$ et al. WHO Classification of Tumours of Haematopoietics and Lymphoid Tissue. IARC Lyon, 2017

5. Rao IS. Role of immunohistochemistry in lymphoma. Indian Journal of Medical and Paediatric Oncology. 2010; 31: 14547.

6. Boffetta P. Epidemiology of adult non-Hodgkin lymphoma. Annals of Oncology. 2011; 22: 27-31

7. Alexander DD, Mink PJ, Adami H, Chang ET, Cole P, Mandel JS et al. The non-Hodgkin Lymphomas: a review of the epidemiologic literature. International Journal Cancer. 2007; 22: $1-39$.

8. Al-Hamadani M, Habermann TM, Cerhan JR, Macon WR, Maurer MJ, Go RS et al. Non-Hodgkin Lymphoma subtypes distribution, geodemographic patterns, and survival in US: A longitudinal analysis of the National Cancer data base from 1998. Am J Hematol. 2015; 90: 790-95.

9. Groves FD, Linet MS, Travis LB, Devesa SS. Cancer surveillance series: Non-Hodgkin's lymphoma incidence by histologic subtype in the United States from 1978 through 1995. J Natl Cancer Inst.2000; 92:1240-51.

10. Akhter A, Rahman MR, Majid N, Shermin S, Saleheen MS, Rajib RC et al. Histological subtypeps of Non Hodgkin's Lymphoma in different age and sex groups. Bangladesh Medical Journal. 2012; 41: 32-36.

11. Laurini JA, Perry AM, Boilesen E, Maclennan KA, MüllerHermelink HK, Nathwani BN et al. Classification of nonHodgkin lymphoma in Central and South America: a review of 1028 cases. Blood. 2012;120: 4795-4801.

12. Dotlic S, Perry AM, Petrusevska G, Fetica B, Diebold J, MacLennan KA et al. Classification of non-Hodgkin lymphoma in South-eastern Europe: review of 632 cases from the International non-Hodgkin Lymphoma Classification Project. Br J Haematol. 2015; 171:366-72. 
13. Perry AM, Perner Y, Diebold J, Nathwani BN, MacLennan KA, Mullr-Hermelink HK et al. Non-Hodgkin lymphoma in Southern Africa: review of 487 cases from the International Non-Hodgkin Lymphoma Classification Project. Br J Haematol. 2016; 172:716-23.

14. Perry AM, Diebold J, Nathwani BN, MacLennan KA, MullrHermelink HK, Bast $\mathrm{M}$ et al. Relative frequency of nonHodgkin lymphoma subtypes in selected centres in North Africa, the Middle East and India: a review of 971 cases. $\mathrm{Br}$ J Haematol. 2015; 172:699-708.

15. Perry AM, Diebold J, Nathwani BN, MacLennan KA, MullrHermelink HK, Bast $M$ et al. Non-Hodgkin lymphoma in the Far East: review of 730 cases from the International nonHodgkin Lymphoma Classification Project. Ann Hematol. 2016; 95:245-51.

16. Perry AM, Diebold J, Nathwani BN, MacLennan KA, MullrHermelink HK, Bast M et al. Non-Hodgkin lymphoma in the developing world: review of 4539 cases from the International Non-Hodgkin Lymphoma Classification Project. Haematologica. 2016; 101:1244-50.

17. Horesh N, Horowith NA. Does Gender Matter in NonHodgkin Lymphoma? Differences in Epidemiology, Clinical Behavior, and Therapy. Rambam Maimonides Med J. 2014;5:e038.

18. Manipadam MT, Nair S, Viswbandya A, Mathew L, Srivastva A, Chandy M. Non Hodgkin lymphoma in childhood and adolescence: frequency and distribution of immunomorphological types from a tertiary care center in South India. World Journal of Pediatrics. 2011;7: 318-22.

19. Pedrosa FP, Pedrosa F, Lins MM, Pontes NT, Falbo GH. NonHodgkin's lymphoma in childhood: clinical and epidemiological characteristics and survival analysis at a single center in Northeast Brazil. Jornal de Pediatria. 2007; 83:547-54.

20. Smith A, Crouch S, Lax S, Ruizhe li J, Painter D, Howell DA et al. Lymphoma incidence, survival and prevalence 20042014: sub-type analyses from the UK's Haematological Malignancy Research Network. British Journal of Cancer. 2015;112: 575-84

21. Mitterlechner T, Fiegl M, Muhlbock H. Epidemiology of nonHodgkin lymphomas in Tyrol/Austria from 1991 to 2000. J Clin Pathol. 2006;59:48-55

22. Nair R, Arora N, Mallath, M.K. Epidemiology of NonHodgkin Lymphoma in India. Oncology 2016; 91: 18-25.

23. Krivolapov IuA. The results of histological and immunohistological studies of primary biopsies in 400 patients with non-Hodgkin's lymphoma in the North-West region of Russia (according to WHO classification)]. Ter Arkh. 2004;76: 64-70

24. Sachdev R, Duggal R, Agarwal K, Goel S. Coexistent Nodal Diffuse Large B-cell Lymphoma with Extrapulmonary Tuberculosis: A rare case. Int J Surg Pathol. 2016; 24: 70-72

25. Naresh KN, Srinivas V, Soman CS. Distribution of various subtypes of non-Hodgkin's lymphoma in India: a study of 2773 lymphomas using R.E.A.L. and WHO Classifications. Ann Oncol. 2000; 11:63-67.

26. Vannata B, Zucca E. Primary Extranodal B-cell lymphoma: current concepts and treatment strategies. Chinese Clinical Oncology. 2014;4:10

27. Pai A, Kannan T, Balambika RG, Vasini V. A Study of Clinical Profile of Primary Extranodal Lymphomas in a Tertiary Care Institute in South India. Indian J Med Paediatr Oncol. 2017; 38: 251-55. 